\title{
ПОЛЕСЬЯ: ПРОБЛЕМЫ РАЦИОНАЛЬНОГО ИСПОЛЬЗОВАНИЯ ПРИРОДНЫХ РЕСУРСОВ И УСТОЙЧИВОЕ РАЗВИТИЕ
}

14-17 сентября 2016 г. в г. Минске проведена Международная научная конференция “Проблемы рационального использования природных ресурсов и устойчивое развитие Полесья”. Конференция была организована Национальной академией наук Беларуси совместно с Российской академией наук, Польской академией наук, Национальной академией наук Украины, Министерством природных ресурсов и охраны окружающей среды Республики Беларусь, Государственным комитетом по науке и технологиям Республики Беларусь, Белорусским республиканским фондом фундаментальных исследований, Министерством образования и науки Российской Федерации, Национальной академией аграрных наук Украины.

Полесья - обширный пояс низменностей, занимающих 20 млн га от Карпат до Урала в пределах Польши, Украины, Беларуси и России. Для них характерны широкое распространение болот и переувлажненных земель, значительная мелиоративная преобразованность при одновременной сохранности больших массивов малоизмененных болотных ландшафтов, ценных для сохранения ландшафтного и биологического разнообразия и экосистемных услуг.

Конференция проведена с целью обобщения имеющегося в разных странах опыта использования природных ресурсов и сохранения уникальных полесских ландшафтов, выбора научно-технических приоритетов в области природо- и недропользования, обеспечивающих устойчивое социально-экономическое развитие полесских регионов.

В конференции приняли участие более 350 ученых и специалистов из Беларуси, Польши, России, Украины, Германии и Хорватии.

Конференция включала пленарные заседания, работу 5 секций, 2 научные полевые экскурсии на территорию Белорусского Полесья.

Во время открытия конференции с приветственным словом к участникам обратился Председатель оргкомитета конференции, Председатель Президиума Национальной академии наук Беларуси, академик НАН Беларуси В. Г. Гусаков. Участников конференции приветствовали также министр природных ресурсов и охраны окружающей среды Республики Беларусь А. М. Ковхуто, директор Института географии и пространственной организации Польской академии наук профессор Марек Дегорски, член-корреспондент Российской академии наук В.А. Снытко, директор Института географии Национальной академии наук Украины академик НАН Украины Л. Г. Руденко.

Участниками конференции были представлены 280 докладов по широкому спектру вопросов, касающихся состояния и использования природных ресурсов, социально-экономических и экологических проблем природопользования, сохранения историко-культурного наследия в полесских регионах.

В ходе пленарных заседаний заслушаны 16 докладов. Доклад Председателя Президиума НАН Беларуси академика НАН Беларуси В.Г. Гусакова и директора Института природопользования НАН Беларуси академика НАН Беларуси А. К. Карабанова был посвящен анализу особенностей природопользования в Белорусском Полесье и обоснованию приоритетных направлений научных исследований в данной области. Особенности и тенденции развития Украинского Полесья были освещены в докладе академика НАН Украины Л. Г. Руденко (соавторы А. И. Бочковская и Е.А. Поливач). В докладе профессора М. Дегорского был охарактеризован природный потенциал Западного Полесья и было показано, что качество природной среды может рассматриваться как важный фактор устойчивого развития только при условии осознания местным населением его ценности.

Вопросам мелиоративной освоенности Полесского региона, эффективности мелиорации и сельскохозяйственного использования земель в разных странах были посвящены доклады директора Института водных проблем и мелиорации НААН Украины академика НААН Украины М.И. Ромащенко, директора Института мелиорации НАН Беларуси к.т.н. Н.К. Вахонина и главного научного сотрудника этого же института д.с.-х.н. 
А. С. Мееровского. Проблемам постмелиоративного использования земель Мешерской низменности был посвящен доклад заведующего кафедрой физической географии и ландшафтоведения географического факультета МГУ члена-корреспондента РАН К. Н. Дьяконова и соавторов П. И. Пыленка и Т.И. Харитоновой. Проблемы сохранения природных комплексов Полесья в условиях широкомасштабной мелиоративной освоенности были представлены в докладе академика НАН Беларуси В. И. Парфенова.

Результаты новейших исследований химии воды были представлены в докладе директора Института коллоидной химии НАН Украины академика НАН Украины В.В. Гончарука, а структура и водные свойства торфа, перспективные направления его использования, включая глубокую переработку - в докладе академика НАН Беларуси И. И. Лиштвана.

Проблемам радиоактивного загрязнения почв/ земель Полесского региона и их восстановлению были посвящены доклады главного научного сотрудника Института почвоведения и агрохимии НАН Беларуси академика НАН Беларуси И. М. Богдевича и директора Института агроэкологии и природопользования НААН Украины академика НААН Украины А.Г. Тарарико (соавторы В.П. Ландин, М.Ю. Тарарико, В.А. Захарчук, А.А. Мельничук).

О разнообразии минерально-сырьевых ресурсов в Украинском Полесье и перспективах их использования говорилось в докладе Председателя Государственной комиссии Украины по запасам полезных ископаемых профессора Г. И. Рудько.

Значимости для Полесского региона и мировой сети охраняемых территорий трансграничного трехстороннего биосферного заповедника "Западное Полесье” (Польша, Беларусь, Украина) был посвящен доклад профессора Романа Сойя из Института географии и пространственной организации Польской академии наук.

Заместитель директора Института природопользования НАН Беларуси, д.г.н. В. С. Хомич от группы соавторов - М. И. Струка, А. К. Карабанова, И.И. Лиштвана, И. М. Богдевича, А.В.Пугачевского, О.В.Кадацкой, Б. В. Курзо, Э.Н. Шкутова, Н.А. Юргенсон и Е.В. Санец - представил доклад о состоянии и стратегических направлениях использования природных ресурсов Припятского Полесья, подготовленный по результатам научного обеспечения Государственной программы социально-экономического развития и комплексного использования природных ресурсов Припятского Полесья, реализованной в 2010-2015 гг.

Второй день работы конференции был посвящен обсуждению различных аспектов развития Полесского региона на секционных заседаниях. Результаты работы секций были обсуждены на заключительном пленарном заседании. По результатам обсуждения было рекомендовано учреждениям академий наук Беларуси, Польши, России и Украины, учреждениям науки и образования других министерств включить в планы работ комплекс научных и научно-практических задач, обеспечивающих повышение эффективности использования природных ресурсов и сохранение уникальных ландшафтов полесий:

\section{в области климатических исследований:}

- изучение тенденции и разработка научного прогноза климатических изменений в Полесье, повторяемости экстремальных погодных и климатических явлений под влиянием естественных и антропогенных факторов;

в области рационального использования водных и земельных ресурсов, гидромелиораций:

- внедрение бассейнового подхода в управлении водными ресурсами Полесского региона;

- обоснование с учетом тенденций аридизации климата и реализация мер по эффективному использованию осушительно-увлажнительных систем, восстановлению гарантированных водоисточников (прудов, водохранилищ), сохранению влагозапасов и их рациональному использованию;

- разработка системы мелиоративного земледелия и луговодства, адаптированной к изменяющимся почвенно-гидрологическим условиям и обеспечивающей минимизацию потерь органического вещества на основе культивирования многолетних бобовых и злаковых трав;

- дальнейшая корректировка специализации и сбалансированная интенсификация земледелия в сельскохозяйственных организациях, на землях которых преобладают малопродуктивные, зачастую переувлажненные, песчаные и торфяные почвы, характеризующиеся высокими коэффициентами перехода ${ }^{137} \mathrm{Cs}$ и ${ }^{90} \mathrm{Sr}$ в продукцию, которая зачастую убыточна;

в области рационального использования минерально-сырьевых ресурсов:

- разработка научно-обоснованных технологий глубокой переработки и комплексного использования промышленно значимых видов минерально-сырьевых ресурсов Полесья; 
в области рационального использования биологических ресурсов и сохранения биоразнообразия:

- разработка комплекса мероприятий по охране уникальных ландшафтов Полесья, увязке ООПТ и экологических сетей в трансграничном аспекте;

- разработка комплекса мер и мероприятий по предотвращению негативных тенденций в изменении биологического разнообразия Полесья, трансграничных инвазий чужеродных видов растений и животных;

- разработка стратегии устойчивого развития Беловежского экологического региона как проблемного в контексте высокой антропогенной нагрузки.

В ходе работы конференции были проведены 2 научные полевые экскурсии на территорию Полесья: в Солигорский район (Минская область) и на Полесскую опытную станцию мелиоративного земледелия и луговодства НАН Беларуси
(Брестская область, Лунинецкий район). Во время экскурсий были обсуждены проблемы использования и охраны торфяно-болотных почв и торфяных месторождений, проблемы мелиорации и использования мелиорированных земель, методы предотвращения деградации осушенных торфяных почв и сохранения органического вещества при их сельскохозяйственном использовании.

Представленные на конференции научные доклады опубликованы в сборнике докладов конференции в 2-х томах: Проблемы рационального использования природных ресурсов и устойчивое развитие Полесья: сб. докл. Междунар. науч. конф. (Минск, 14-17 сентября 2016 г.) / Нац. акад. наук Беларуси и др. / Гл. ред. В. Г. Гусаков. Минск: Беларуская навука, 2016. Т. 1. 618 с.; Т. 2. 691 с. (www. ecology.basnet.by).

Леонид Г. Руденко, Валериан А. Снытко, Валерий С. Хомич 


\begin{tabular}{llllc}
\hline Сдано в набор 30.03.2017 г. & Подписано в печать & 17.05 .2017 г. Дата выхода в свет 27.06.2017 г. & Формат $60 \times 88^{1} / 8$ \\
Офсетная печать & Усл.печ.л. 16.5 & Усл.кр.-отт. 2.2 тыс. & Уч.-изд.л. 16.5 & Бум.л. 8.25 \\
& Тираж 130 экз. & Зак. 467 & Цена свободная & \\
\hline
\end{tabular}

Учредители: Российская академия наук, Институт государства и права РАН

Издатель: ФГУП «Издательство “Наука”», 117997 Москва, Профсоюзная ул., 90

Оригинал-макет подготовлен ФГУП «Издательство “Наука”»

Отпечатано в ФГУП «Издательство “Наука” («Типография “Наука”)), 121099 Москва, Шубинский пер., 6 